\title{
Кластеризация генов митохондрий грибов и растений по триплетному составу выявляет структурированность этих данных
}

\author{
Федотовская В.Д. ${ }^{*}$, Шпагина Т.О. ${ }^{1}$, Колесникова А.И. ${ }^{1}$, Садовский М.Г. ${ }^{1,2}$ \\ ${ }^{1}$ Сибирский федеральный университет, Институт фундаментальной биологии и биотехнологии, \\ Красноярск, Россия \\ ${ }^{2}$ Институт вычислительного моделирования СО РАН, Красноярск, Россия \\ *viktoriia.fedotovskaia@gmail.com
}

Ключевые слова: структура, функция, нуклеотидные последовательности, упругие карты, митохондриальные гены

Мотивация и цุель: Выявление связи между структурой биологической молекулы (в данном случае последовательности ДНК) и ее функцией - одна из фундаментальных задач биоинформатики, далекая от решения. Исследования, посвященные этой теме, зависят от выбранного материала. Ранее указанная связь исследовалась на геномах хлоропластов [1] и на последовательности РНК генов бактерий [2].

Meтоды $и$ алгоритмы: В данной работе связь между структурой, функцией и таксономией изучали на примере митохондриальных генов АТФ-синтаз грибов $(a t p 6, a t p 8$ и $a t p 9)$ и растений (atp $1, a t p 4, a t p 6, a t p 8$ и atp9). Исследовали 223 генома грибов и 85 геномов растений. Из полных митохондриальных геномов были выделены последовательности указанных генов. Каждая последовательность преобразовывалась в частотный словарь триплетов с шагом рамки считывания $t=1$. Далее на упругих картах рассматривалось распределение генов в 64-мерном пространстве, в котором осями являлись частоты триплетов. Последовательности растений и грибов рассматривались по отдельности, на разных упругих картах.

Результаты: Распределение генов на упругой карте оказалось упорядоченным: выделялись кластеры, точки в которых соответствуют одинаковым генам. Таким образом, на упругой карте с последовательностями генов грибов выделились три кластера, в каждом из которых оказались точки, соответствующие одному и тому же гену. Соответственно, на упругой карте с последовательностями генов растений обнаружилось пять геноспецифичных по составу кластеров. Связи между составом кластеров и таксономией не найдено.

Заключение и доступность: При кластеризации последовательностей генов АТФсинтаз грибов и растений методом упругих карт доказано преобладание функции над таксономией. Данный генетический материал является специфичным, поэтому мы не можем утверждать, что обнаруженный эффект универсален.

\section{Список литературь}

1. Sadovsky M. et al. Genome structure of organelles strongly relates to taxonomy of bearers. Bioinformatics Biomedical Engineering. 2015:481-490.

2. Горбань А.Н. Классификация нуклеотидных последовательностей по частотным словарям обнаруживает связь между их структурой и таксономическим положением организмов. Журн. общ. биологии. 2003:64(1):65-77. 